\title{
Metformin improves the angiogenic functions of endothelial progenitor cells via activating AMPK/eNOS pathway in diabetic mice
}

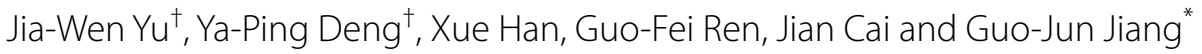

\begin{abstract}
Background: Endothelial dysfunction has been suggested as a possible causal link between hyperglycemia and microvascular complications in diabetes mellitus. The effect of metformin on endothelial progenitor cells (EPCs) is still unclear. This study was designed to test the hypothesis that metformin could accelerate wound healing by improving the impaired EPC functions in streptozotocin-induced diabetic mice.

Methods: Streptozotocin (STZ, $60 \mathrm{mg} / \mathrm{kg} / \mathrm{d} \times 5$ d, i.p.) was injected to induce type 1 diabetes in male C57BL/6 mice. Mice were treated with metformin $(250 \mathrm{mg} / \mathrm{kg} / \mathrm{d}, \mathrm{i} . \mathrm{g}$.) for consecutive 14 days. Wound closure was evaluated by wound area and number of CD31 stained capillaries. Functions of bone marrow-endothelial progenitor cells (BMEPCs) were assessed by tube formation and migration assays, and expression of AMP-activated protein kinase (AMPK) and endothelial nitric oxide synthase (eNOS) was determined by western blot analysis.
\end{abstract}

Results: Metformin accelerated wound closure and stimulated angiogenesis in diabetic mice. The number of circulating EPCS was increased significantly in metformin treated diabetic mice. Abilities of tube formation and migration of BM-EPCs were impaired in diabetic mice, which were improved by metformin. Expression of both phosphorylatedAMPK and phosphorylated-eNOS was significantly increased, and nitric oxide (NO) production was enhanced by metformin in BM-EPCs of diabetic mice. In vitro, metformin improved impaired BM-EPC functions, and increased phosphorylated-eNOS expression and NO production in cultured BM-EPCs caused by high glucose, which was prevented by the AMPK inhibitor compound $C$.

Conclusions: Our results suggest that metformin could improve BM-EPC functions in STZ-induced diabetic mice, which was possibly dependent on the AMPK/eNOS pathway.

Keywords: Metformin, Endothelial progenitor cells (EPCs), Angiogenesis, Diabetes mellitus

\section{Background}

Diabetes mellitus is the most serious, chronic metabolic disorder, which is characterized by hyperglycemia, and affecting more than 400 million people worldwide with a predicted $>50 \%$ increase in $2030[1,2]$. In particular, microvascular and macrovascular disease, one of the

\footnotetext{
*Correspondence: jguojun999@163.com

${ }^{\dagger} J$ ia-Wen Yu and Ya-Ping Deng contributed equally to this work Department of Pharmacy, Zhejiang Xiaoshan Hospital, Hangzhou 311202, Zhejiang, China
}

main complications of diabetes, has been proposed as an important risk factor for the death of diabetic patients [3, 4].

Endothelial dysfunction is not only strongly associated with risk of vascular disease, but also the inner cause of impaired wound healing ability $[5,6]$. Endothelial progenitor cells (EPCs) play a primary role in angiogenesis but are functionally impaired in diabetes, which may contribute to endothelial dysfunction [7]. EPCs are vital for the vascular protection and angiogenesis [8]. In patients with diabetes, circulating EPCs number is decreased and 
EPC functions is impaired $[9,10]$, which are believed to be one of the pathogenesis of vascular complications in diabetes, as manifested by impaired wound healing.

Metformin is a biguanide derivative, which is the most widely prescribed oral hypoglycaemic drug for the management of type 2 diabetes mellitus [11, 12]. Several studies have focused on the effects of metformin on EPCs in patients with diabetes, and found that patients with type 2 diabetes treated with metformin had significantly increased number of circulating EPCs [13]. Recent studies demonstrated that activation of AMP-activated protein kinase (AMPK) partly mediated the therapeutic effects of metformin, which stimulated ischemiainduced revascularization in the ischemic hindlimb mice model [14-16]. Furthermore, studies found that clinically relevant concentrations of metformin activated AMPK in cultured endothelial cells (ECs) [17-21]. AMPK is a well conserved heterotrimer protein comprising $\alpha, \beta$, and $\gamma$ subunits, each of which has 2 or 3 genes encoding [22]. Findings support the notion that AMPK was a new regulator of angiogenesis, which was specifically required for ECs migration and differentiation under hypoxia conditions [23, 24]. In addition, it was found that activated AMPK could directly phosphorylate endothelial nitric oxide synthase (eNOS) in ECs and promote endothelial function [25-28]. However, little information exists regarding the role of metformin on EPC functions under diabetic conditions. Thus, our study tested the hypothesis that metformin could accelerate wound healing, at least in part, by improving the angiogenic functions of EPCs with an AMPK related pathway in diabetic mice.

\section{Methods}

\section{Animals and treatments}

Male C57BL/6 mice (6w, 18-20 g), purchased from the Sino-British SIPPR/BK Lab Animal Ltd (Shanghai, China), were housed in controlled conditions (temperature: $23 \pm 2{ }^{\circ} \mathrm{C}$; lighting: 8:00-20:00) and received a standard mouse chow and tap water ad libitum. All the animals used in this work received humane care in compliance with the institutional animal care guidelines and the Guide for Care and Use of Laboratory Animals published by the National Institutes of Health. Mice were injected with streptozotocin (STZ; Amresco, USA; $60 \mathrm{mg} / \mathrm{kg} / \mathrm{d} \times 5 \mathrm{~d}$, i.p.) dissolved in $0.1 \mathrm{mM}$ sodium citrate buffer ( $\mathrm{pH} 4.5)$. Random blood glucose was measured by using the blood glucose monitoring system (MAJOR, Taiwan) with whole blood from the mouse tail vein. On day 21 , mice with the random blood glucose value $\geq 300 \mathrm{mg} / \mathrm{dL}$ were defined as STZ-induced diabetic mice, which were subsequently divided into two groups: treated with metformin $(250 \mathrm{mg} / \mathrm{kg} / \mathrm{d} \times 14 \mathrm{~d}$, i.g. $\mathrm{n}=26)$ or vehicle $(0.5 \%$ CMC-Na $\times 14 \mathrm{~d}$, i.g., $\mathrm{n}=26)$; age-matched mice without STZ treatment served as the control also received vehicle $(0.5 \% \mathrm{CMC}-\mathrm{Na} \times 14 \mathrm{~d}$, i.g., $\mathrm{n}=26)$. On day 35 , mice were used for wound healing experiment, or anesthetized to harvest bone marrow to isolate EPCs (Fig. 1).

\section{Evaluation of wound healing and angiogenesis}

Mice were anesthetized with ketamine (100 mg/kg, i.p.), and fixed to remove hair on the dorsum by swabbing with betadine and $75 \%$ ethanol before wounding [29]. A $6 \mathrm{~mm}$ circular wound was made by punch biopsy, and closure of the wounded area was measured every 2 days until day 10 . The wound area was digitized and areas were calculated.

Skin at the wounded area was harvested on day 3, 6 and 9 after punch biopsy. Evaluation of angiogenesis was conducted by CD31 immunochemistry and hematoxylin staining $[29,30]$. Capillaries were recognized as tubular structures positive for CD31. One slide from each mouse was examined under high-power fields.

\section{Determination of circulating EPCs}

About $0.5 \mathrm{ml}$ blood was harvested from anesthetized mice, and were dissolved in PBS (1:1). The samples were added into $1 \mathrm{ml}$ gradient centrifugation liquid 10831 (Sigma, St. Louis, MO, USA) gently, and followed by $3000 \mathrm{rpm}$ centrifugation for $25 \mathrm{~min}$. The cell layer was extracted and underwent 5 min lysis of erythrocyte. The samples were incubated with FITC-Sca-1 (BD, San Diego, CA, USA) and PE-Flk-1 (BD, San Diego, CA, USA) antibodies for flow cytometry examination [29].

\section{Assessment of BM-EPC functions}

BM-EPCs from C57BL/6 mice were isolated, cultured and identified as previously described [31]. To confirm the BM-EPCs phenotypes, cells were stained for the uptake of Dil-acLDL (Molecular Probes Inc., Eugene, OR, USA) and FITC-labeled Ulex europaeus agglutinin (lectin; Sigma-Aldrich, St. Louis, MO, USA). The abilities of tube formation and migration of BM-EPCs were determined to assess EPC functions. The angiogenic capacity of BM-EPCs was determined by Matrigel tube formation assay. Briefly, BM-EPCs were isolated and cultured

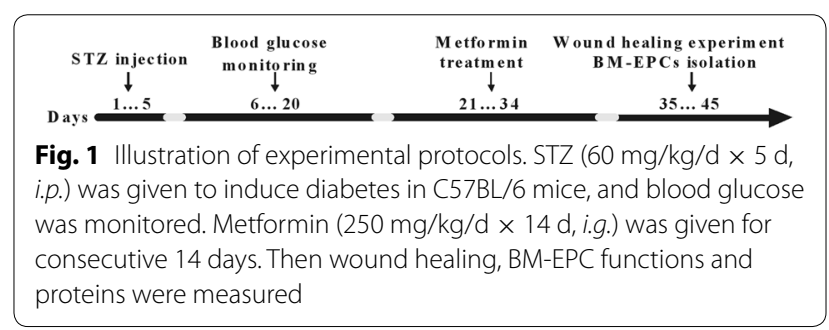


for 7 days, and were harvested using $0.125 \%$ trypsin. The cells with a concentration of $5 \times 10^{4} / 100 \mu \mathrm{l}$ were plated to a 96-well plate pre-coated with $50 \mu \mathrm{l} /$ well growth factor-induced Matrigel (BD Biosciences, Bedford, MA, USA). After $6 \mathrm{~h}$ incubation at $37^{\circ} \mathrm{C}$, tube formation ability of BM-EPCs was evaluated by counting tube numbers. Images of tube morphology were taken under the inverted phase contrast microscope.

The migratory ability of EPCs was assessed by a modified Boyden chamber assay. The cells with a concentration of $5 \times 10^{4} / 100 \mu \mathrm{l}$ were plated on the upper chamber with polycarbonate membrane ( $8 \mu \mathrm{m}$ pores), and VEGF $(50 \mathrm{ng} / \mathrm{ml})$ was added to the cell-free medium in lower chamber of a 24-well Transwell plate (Corning Transwell, Lowell, MA, USA). After incubation at $37^{\circ} \mathrm{C}$ for $24 \mathrm{~h}$, cells were fixed with $2 \%$ paraformaldehyde, and stained by Hoechst $33258(10 \mu \mathrm{g} / \mathrm{ml})$. The migrated cells were observed under the fluorescence microscope.

\section{Determination of SDF-1 a protein by ELISA}

The serum concentration of SDF- $1 \alpha$ protein in mice after metformin treatment was determined by ELISA (R\&D systems, Minneapolis, MN, USA) according to manufacturer's instruction.

\section{In vitro study}

\section{Evaluation of BM-EPC functions}

BM-EPCs were isolated from male C57BL/6 mice, and cultured for 7 days. Medium were replaced with high glucose (HG, 33 mM, M199 containing $27.5 \mathrm{mM}$ D-glucose) medium or high glucose medium containing metformin (2 mM) for $24 \mathrm{~h}$ [32]. The basal M199 containing $5.5 \mathrm{mM}$ glucose (normal glucose, NG) was served as control, and M199 containing $27.5 \mathrm{mM}$ mannitol was used as an osmotic control (Mtol). In addition, metformin ( $2 \mathrm{mM})$ or compound $\mathrm{C}(10 \mu \mathrm{M})$ was added into the medium alone and maintained for $24 \mathrm{~h}$ to see the basal effects of the compounds. Effects of metformin on high glucose induced EPCs dysfunction were assessed by functional analysis.

\section{Measurement of AMPK and eNOS expression}

The samples were prepared as described previously [33]. Protein concentrations were quantified by the BCA Protein Assay Kit (Thermo, Rockford, USA). Samples containing equal amounts of protein were subjected to SDS-PAGE in a Bio-Rad miniature slab gel apparatus and electrophoretically transferred onto a nitrocellulose membrane. The membranes were incubated with $5 \% \mathrm{BSA} / \mathrm{PBST}$ for $1 \mathrm{~h}$ at $25{ }^{\circ} \mathrm{C}$, and incubated overnight at $4{ }^{\circ} \mathrm{C}$ with primary antibodies and $1 \mathrm{~h}$ at $25{ }^{\circ} \mathrm{C}$ with secondary antibodies respectively. Cell Signaling Technology Inc (Danvers, Mass) was the supplier for the following primary antibodies: rabbit polyclonal anti-phospho-eNOS (Ser1177) antibody, rabbit antiphospho-AMPK (Thr172) antibody, rabbit anti-AMPK antibody. Mouse anti-eNOS monoclonal antibody was obtained from BD Transduction Laboratories (Lexington, Ky).

\section{Detection of intracellular NO}

Intracellular NO level was detected by membrane-permeable probes DAF-FM diacetate (Invitrogen, Carlsbad, CA). Briefly, 7 days after BM-EPCs isolation, the cells were harvested using $0.125 \%$ trypsin. After suspension, the samples were incubated with DAF-FM diacetate $\left(10^{-6} \mathrm{~mol} / \mathrm{L}\right)$ for $30 \mathrm{~min}$ at $37^{\circ} \mathrm{C}$ and $30 \mathrm{~min}$ at room temperature in dark respectively for flow cytometry examination.

\section{Statistical analysis}

Data are presented as mean \pm SEM. Statistical analysis was performed by one-way analysis of variance (ANOVA) with Newman-Keuls multiple comparison test. A value of $P<0.05$ was considered to be statistically significant.

\section{Results}

Body weight and blood glucose changes in diabetic mice Blood glucose in STZ-induced diabetic mice was significantly increased ( $384 \pm 10$ vs $162 \pm 8 \mathrm{mg} / \mathrm{dl}, P<0.05$; Fig. 2a), while body weight was significantly decreased when compared with the control after STZ injection on day $20(19 \pm 0.4$ vs $24 \pm 0.6 \mathrm{~g}, P<0.05$; Fig. $2 b)$. Metformin treatment for consecutive 14 days significantly decreased the blood glucose level, but did not modify the body weight in STZ-induced diabetic mice $(P<0.01$; Fig. 2c, d).

\section{Metformin accelerated wound closure and angiogenesis in diabetic mice}

To assess the effects of metformin on wound healing in STZ-induced diabetic mice, the percentage of wound closure was measured every other day until day 10 . Wound healing was significantly slowed in STZ-induced diabetic mice when compared to the control, and metformin significantly accelerated the wound closure $(P<0.05$; Fig. 3a, b) in diabetic mice.

The number of CD31-positive tubular structures in the wounds and surrounding skin were calculated to further evaluate the role of metformin on neovascularization. Capillary formation in STZ-induced diabetic mice was significantly worse on day 3, 6 and 9 when compared to control. However, metformin significantly improved the capillary formation in diabetic mice on day 6 and 9 $(P<0.05$, Fig. 3c, d). 

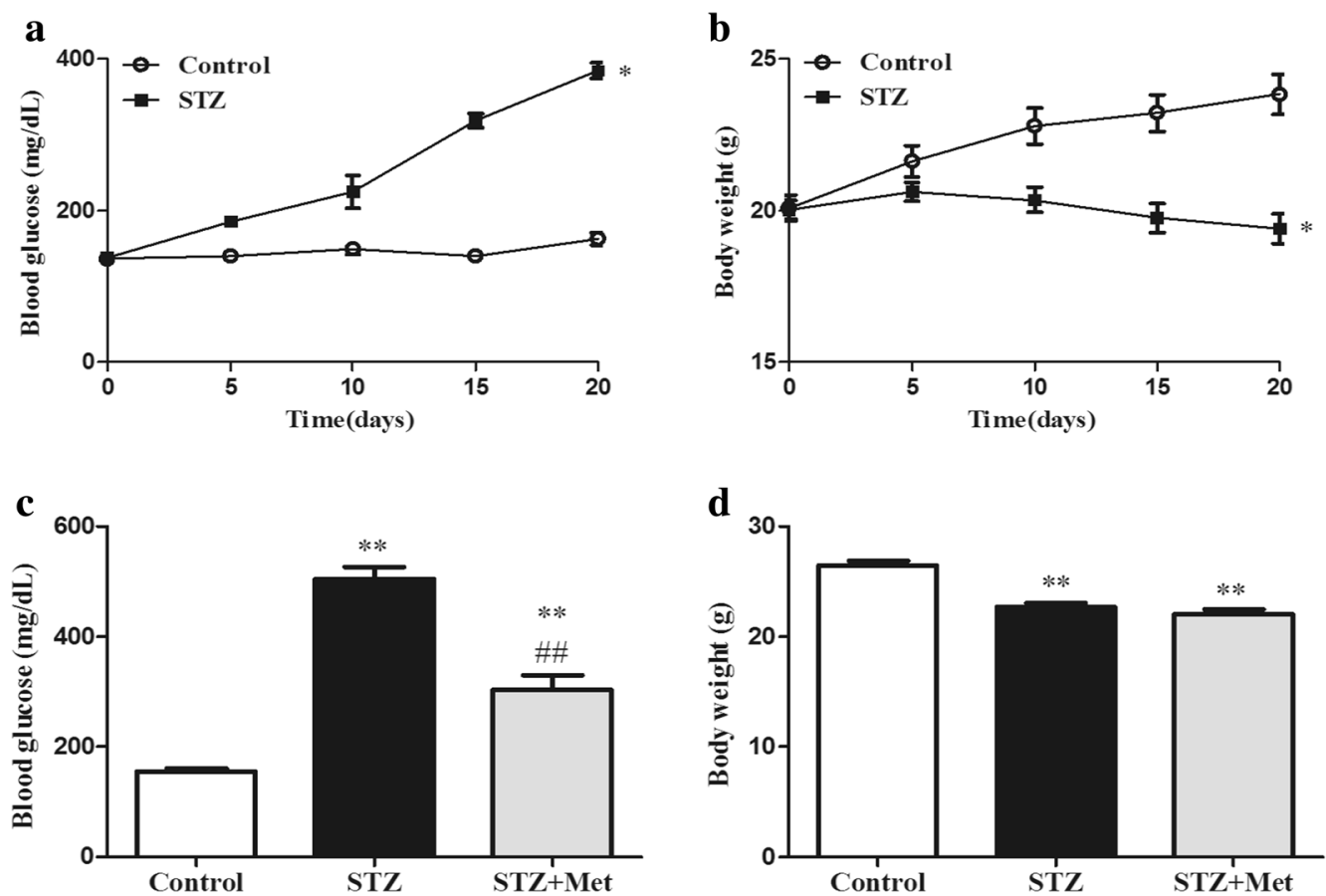

Fig. 2 Establishment of STZ-induced diabetic mice. Compared with the control, mice treated with STZ $(60 \mathrm{mg} / \mathrm{kg} / \mathrm{d} \times 5 \mathrm{~d}$, i.p.) displayed higher blood glucose (a) and lower body weight (b). Metformin $(250 \mathrm{mg} / \mathrm{kg} / \mathrm{d} \times 14 \mathrm{~d}$, i.g.) decreased blood glucose (c), but did not change the body weight (d) in STZ-induced diabetic mice. ${ }^{*} P<0.01,{ }^{*} P<0.05$ vs Control; ${ }^{* \#} P<0.01$ vs STZ. Values are mean \pm SEM $(n=10$ per group)
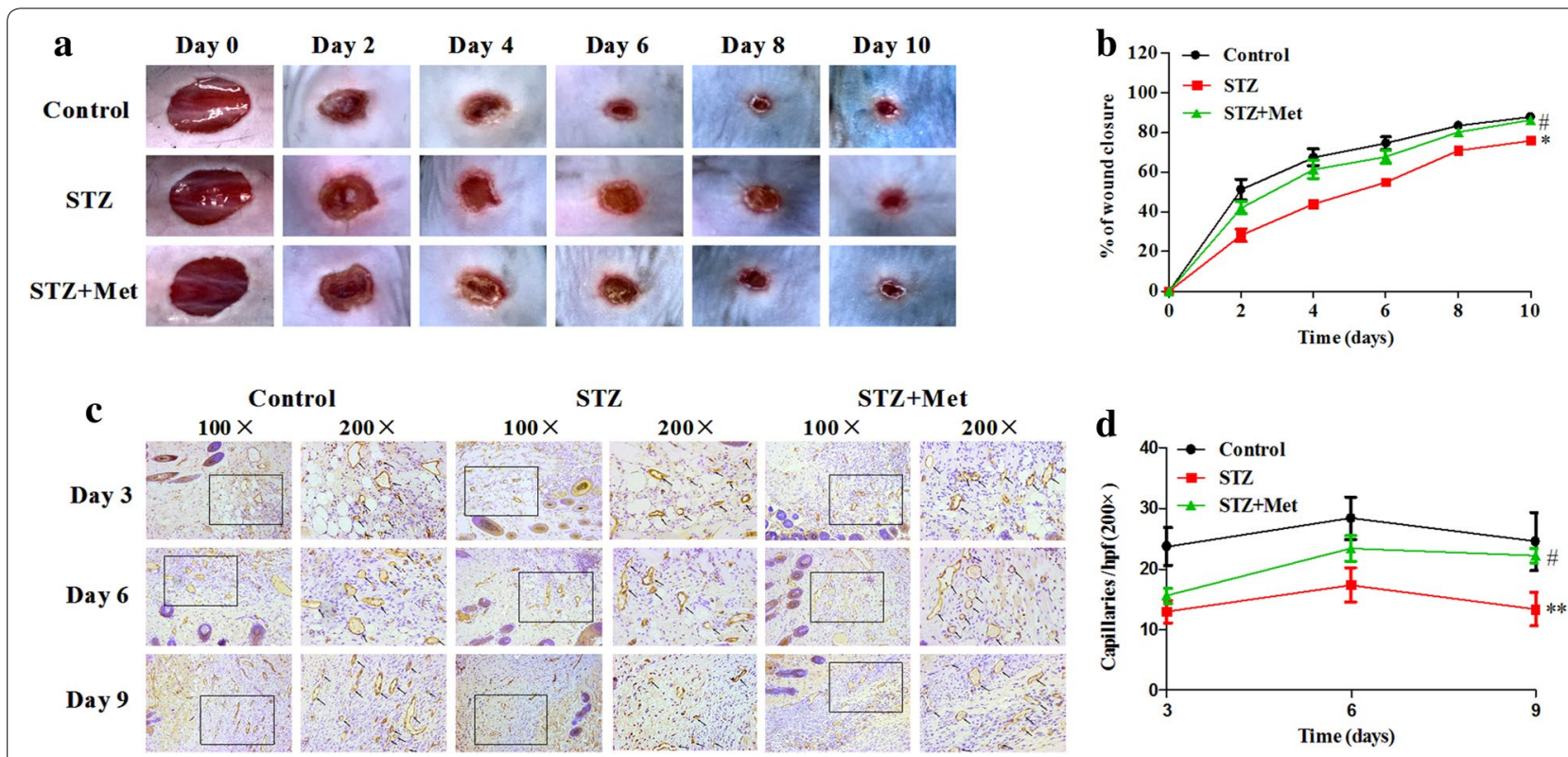

Fig. 3 Metformin accelerated wound healing and stimulated angiogenesis in diabetic mice. Six-mm diameter wound was made by punch biopsy and closure of the wound area was measured every 2 days until day 10, metformin accelerated wound closure in STZ-induced diabetic mice (a, b). Typical photographs of CD31-positive staining on the wounded area were obtained on day 3, 6 and 9 (c, d). ${ }^{*} P<0.01,{ }^{*} P<0.05$ vs Control; ${ }^{*} P<0.05$ vs STZ. Values are mean \pm SEM ( $n=5$ per group) 


\section{Metformin improved BM-EPC functions in diabetic mice}

To test that metformin increased the capillary densities by improving the angiogenic functions of EPCs in STZ-induced diabetic mice, the capacities of tube formation and migration of BM-EPCs were assessed. It was found that functions of BM-EPCs in diabetic mice were significantly lower compared to control. Metformin significantly increased both the capacities of tube formation $(0.70 \pm 0.04$ vs $0.54 \pm 0.04, P<0.05$; Fig. $4 a, b)$ and migration $(0.66 \pm 0.08$ vs $0.37 \pm 0.06, P<0.05$; Fig. $4 \mathrm{c}, \mathrm{d})$ in STZ-induced diabetic mice. Moreover, metformin significantly increased circulating EPCs in STZ-induced diabetic mice $(2.18 \pm 0.32$ vs $1.11 \pm 0.18 \%, P<0.05$; Fig. $4 \mathrm{e}$, f). In addition, we found that the serum concentration of SDF-1 $\alpha$ protein was not changed after metformin treatment (Additional file 1: Figure S1).

\section{Metformin alleviated high glucose-induced dysfunction of BM-EPCs in vitro}

BM-EPCs from C57BL/6 mice were identified as DilacLDL and lectin double-positive cells under a fluorescence microscope (Additional file 2: Figure S2). To investigate whether the effect of metformin on EPCs in diabetic mice was directly related to the high glucose, high glucose was used to induce BM-EPC dysfunction in vitro. High glucose significantly decreased both the capacities of tube formation and migration in cultured BM-EPCs compared to the control. Metformin improved impaired BM-EPC functions caused by high glucose (Tube formation: $0.80 \pm 0.03$ vs $0.62 \pm 0.03$; Migration: $1.04 \pm 0.12$ vs $0.59 \pm 0.03, P<0.05$; Fig. 5). However, compared with the NG, BM-EPCs treated with mannitol (served as the osmotic control for the HG) showed no significant changes in tube formation and migration (Additional file 3: Figure S3).

\section{Metformin increased both AMPK and eNOS} phosphorylated-to-total ratio in BM-EPCs in diabetic mice Expression of AMPK and eNOS in BM-EPCs of STZinduced diabetic mice was determined. Western blot analysis found that total AMPK and eNOS protein in BM-EPCs showed no difference among groups. However, both phosphorylated-AMPK and phosphorylated-eNOS expression in BM-EPCs were decreased in STZ-induced diabetic mice compared to the control. Metformin increased both phosphorylated-AMPK and phosphorylated-eNOS expression in BM-EPCs of the diabetic mice $(P<0.05$; Fig. 6). Meanwhile, it was found that the intracellular NO level in BM-EPCs was significantly decreased in STZ-induced diabetic mice, and metformin increased the intracellular NO level $(P<0.05$; Fig. 6).

\section{Metformin increased phosphorylated-eNOS in BM-EPCs via an AMPK dependent pathway in vitro}

To explore whether expression of phosphorylated eNOS was determined by activation of AMPK, phosphorylatedeNOS expression in BM-EPCs in vitro was measured when AMPK inhibitor was used. Similarly, high glucose induced decreased phosphorylated-eNOS in vitro, and metformin significantly prevented the change caused by high glucose. Importantly, inhibition of AMPK by compound $\mathrm{C}$ significantly inhibited phosphorylated-eNOS expression enhanced by metformin in BM-EPCs cultured in vitro $(P<0.05$; Fig. 7$)$. In addition, metformin reversed intracellular $\mathrm{NO}$ production caused by high glucose, which was prevented by inhibiting AMPK with compound $C(P<0.05$; Fig. 7$)$. Metformin alone did not change BM-EPC functions of both tube formation and migration, while compound $\mathrm{C}$ significantly inhibited tube formation, but not migration (Additional file 4: Figure S4).

\section{Discussion}

In the present study, we found that: (1) metformin accelerated wound healing and stimulated angiogenesis, improved the impaired EPC capacity, and increased NO production in BM-EPCs of STZ-induced diabetic mice; (2) In vitro, metformin improved high glucose-impaired EPC function, and enhanced intracellular NO level; (3) the protective effects of metformin on BM-EPCs were possibly related to activating AMPK/eNOS pathway.

Wound healing involves an integrative interplay of cells, mediators, growth factors, and cytokines, which is responded to tissue injury [34, 35]. Under diabetic condition, impaired wound healing and reduced vascular repair may be a consequence of a metabolic derangement $[34,36,37]$. In addition, chronic hyperglycemia has been reported to be responsible for the onset of microvascular complications, including the diabetic foot ulcer and risk for amputation [38]. Angiogenesis plays a significant role in skin maintenance and repair, depending on various cell participation and coordination, especially EPCs [39, 40]. However, much of the complexity of the angiogenesis has not yet to be defined [34].

Metformin is one of the most widely used drugs for the treatment of type 2 diabetes, which improves vascular endothelial functions in type 2 diabetic patients, although its mechanisms remain largely unknown [41]. Recently, several studies showed the paradoxical effects of metformin on the angiogenesis. In general, metformin was considered to down-regulate tumor angiogenesis [42, 43]. However, in disease models such as heart failure and diabetes, metformin was associated with enhanced angiogenesis [12, 44, 45]. It was also found that metformin prevented partially insulin-deficient diabetes-induced 
$\mathbf{a}$
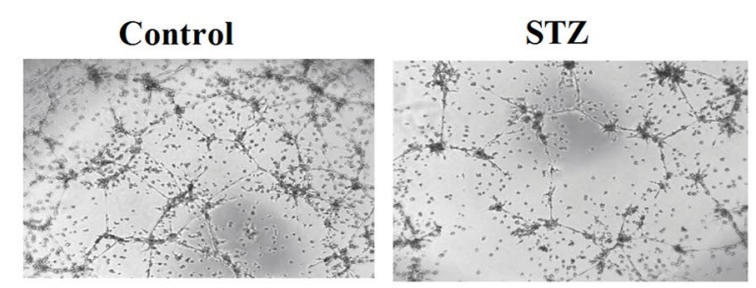

c
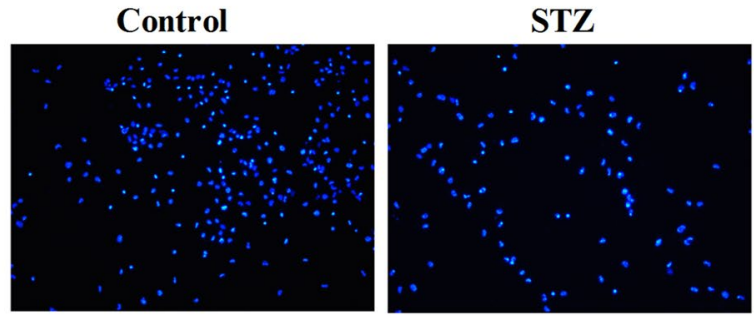

e
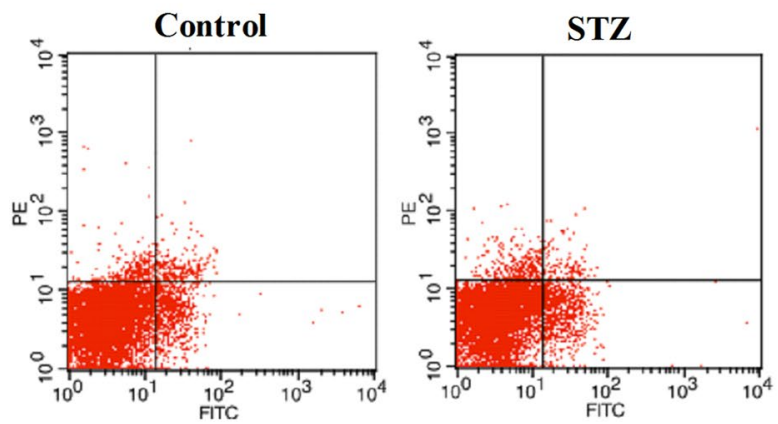
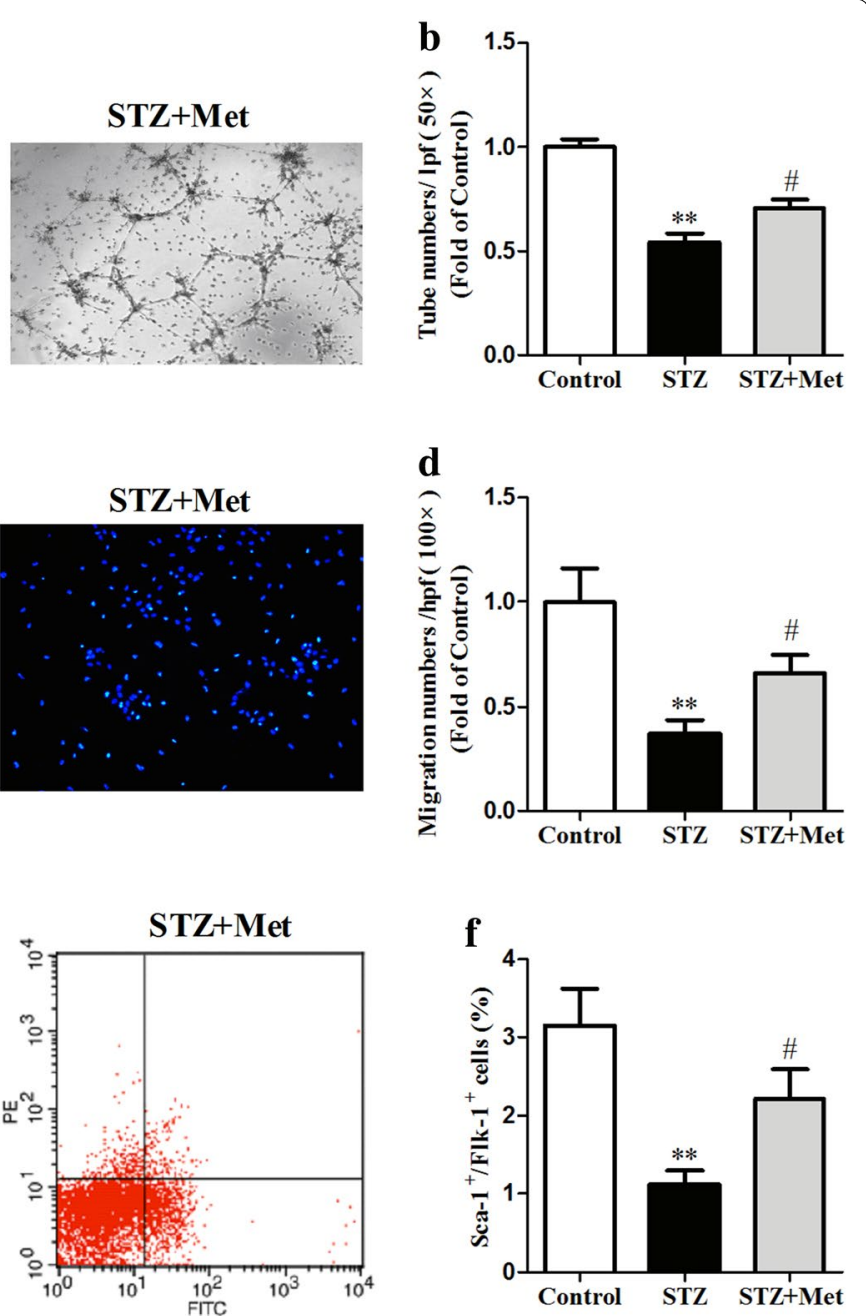

Fig. 4 Metformin improved BM-EPC functions in diabetic mice. BM-EPCs from anesthetized mice were isolated and cultured. Metfromin improved the tube formation $(\mathbf{a}, \mathbf{b})$ and migration $(\mathbf{c}, \mathbf{d})$ ability of BM-EPCs. Blood was harvested from anesthetized mice. Metformin increased circulating EPCs in STZ-induced diabetic mice $(\mathbf{e}, \mathbf{f}) .{ }^{* *} P<0.01$ vs Control; ${ }^{\#} P<0.05$ vs STZ. Values are mean \pm SEM ( $n=6$ per group)

bone microarchitecture alterations [46], and enhance the process of bone repair in diabetic and nondiabetic rats [47]. Other anti-diabetic drugs, such as dipeptidyl peptidase-4 (DPP-4) and alpha-glucosidase inhibitor could also improve endothelial function in patients with type 2 diabetes [48], rosiglitazone could improve angiogenic potential of diabetic ECs and proangiogenic cells (PACs) [49]. In our work, we found that metformin $(250 \mathrm{mg} /$ $\mathrm{kg} / \mathrm{d} \times 14 \mathrm{~d}$, i.g.) did increase the capillary densities and the percentage of wound closure in STZ-induced diabetic mice. Thus, we further explored the effect of metformin on BM-EPC functions in STZ-induced diabetic mice.

Endothelial monolayer is necessary for preserving the integrity of vasculature [50]. The functional activity and even the structure of endothelial cells are impaired under diabetic conditions, which may contribute to microvascular and macrovascular abnormalities [51]. EPCs, a group of multi-progenitor cells, can differentiate into endothelial cells, and make up the lining of blood vessels [52]. EPCs are important precursors of endothelial cell, and it has been shown that EPCs were involved in angiogenesis and wound repair in diabetic patients [5355]. Importantly, systematic administration of EPCs could significantly improve angiogenesis and wound healing in a mouse model of type 2 diabetes [56]. These suggest that improvement of EPC function or increase of circulating EPCs might be clinically significance with treatment of certain specific drugs, especially for diabetic vascular complications. It was found that the percentage of circulating EPCs and functions of BM-EPCs in diabetic mice were significantly lower compared with the control. Metformin treatment significantly prevented these changes in 

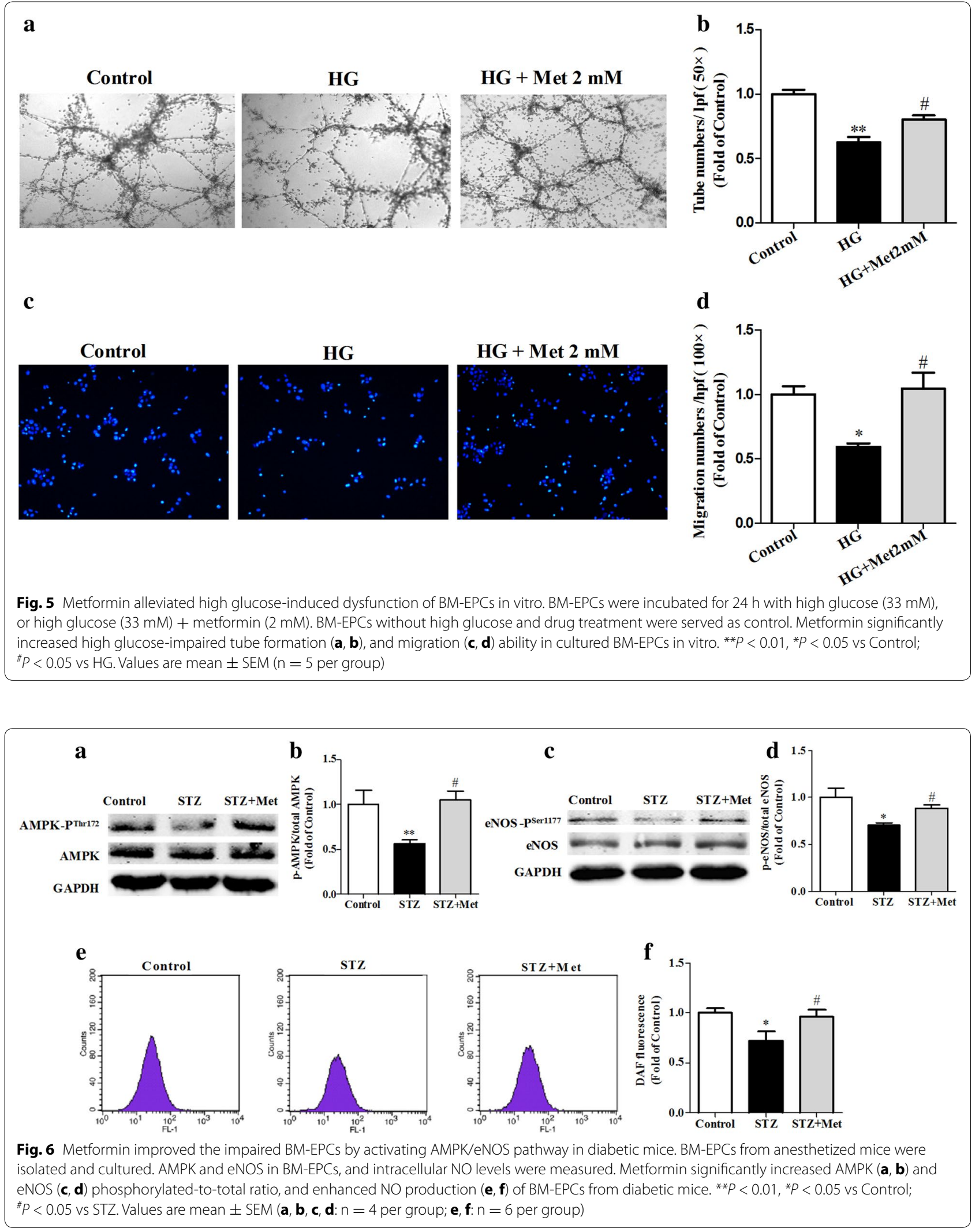


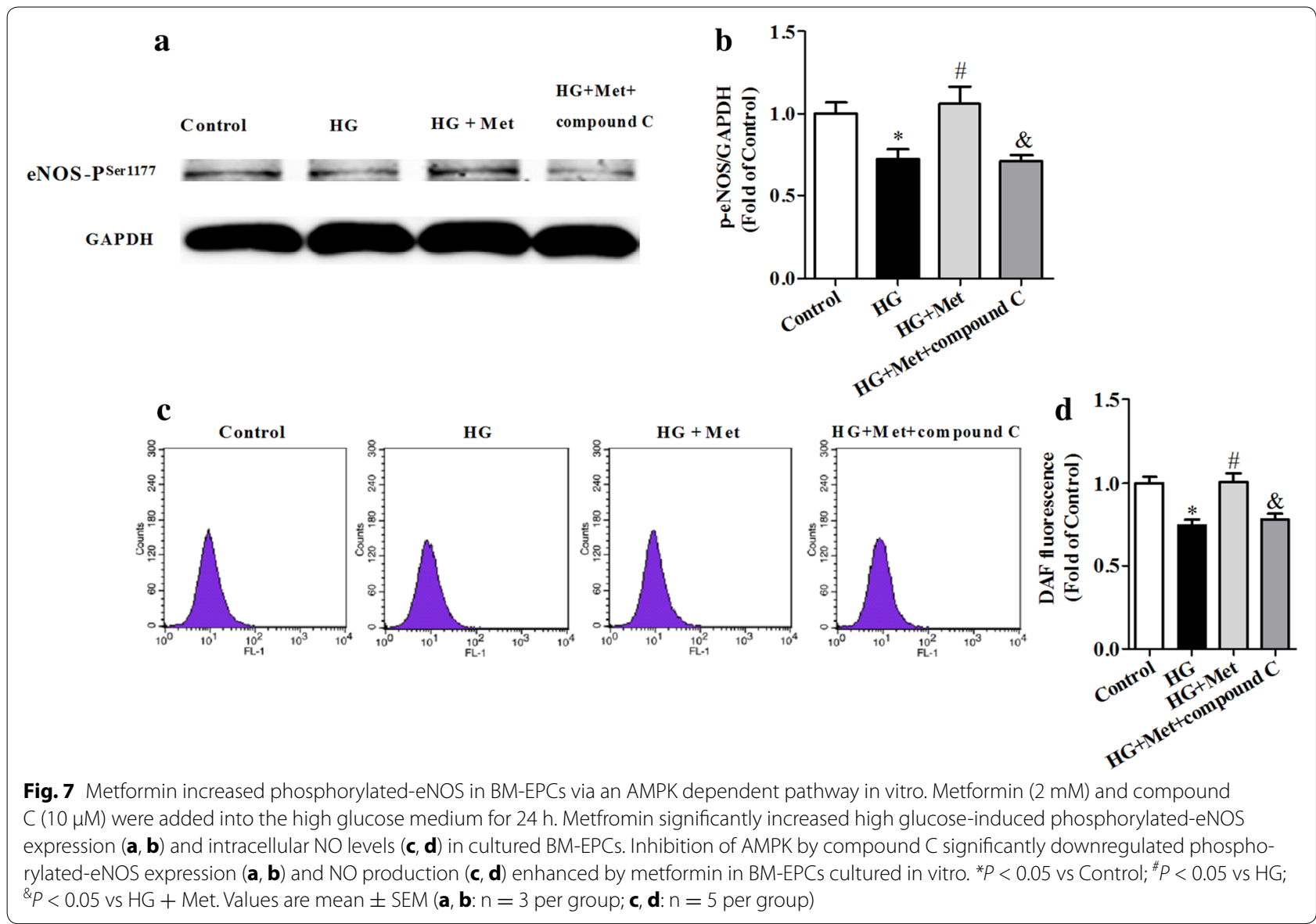

diabetic mice. In addition, metformin treatment improved impaired BM-EPC function caused by high glucose. Thus, we postulated that the effect of metformin in accelerating wound healing under diabetic condition was possibly related to improving impaired BM-EPC functions and increasing circulating EPCs number.

Dysfunction of EPCs contributes to the pathogenesis of diabetes, and the main cause of EPC dysfunction is the loss of protection from NO due to reduced synthesis from eNOS $[57,58]$. One of the AMPK targets that may be particularly important in the circulatory system is the eNOS [59]. Moreover, AMPK was suggested as a drug target for diabetes mellitus, including drugs as metformin [60]. Activation of AMPK by metformin could protect human coronary artery endothelial cells and against diabetic lipoapoptosis [61]. In our work, metformin significantly increased both AMPK and eNOS phosphorylated-to-total ratio, and enhanced NO production of BM-EPCs from diabetic mice. In vitro, metfromin increased both phosphorylated-eNOS expression and intracellular NO levels in cultured BM-EPCs. Importantly, inhibition of AMPK by compound C prevented these changes by metformin. These indicated that the beneficial effect of metformin on BM-EPC functions in STZ-induced diabetic mice was related to activating AMPK/eNOS pathway.

\section{Conclusions}

In summary, our work demonstrated that metformin could accelerate wound healing, stimulate angiogenesis, improve the impaired BM-EPC functions, and increase both phosphorylated-AMPK and phosphorylated-eNOS expression in BM-EPCs from STZ-induced diabetic mice. In vitro, metformin could improve high glucose-impaired BM-EPC functions, and increase phosphorylated-eNOS expression and NO production in BM-EPCs caused by high glucose. These together suggest that metformin may improve BM-EPC functions in diabetic mice possibly with an AMPK/eNOS dependent pathway. 


\section{Additional files}

Additional file 1: Figure S1. Serum concentration of SDF-1 a protein in mice determined by ELISA. The serum concentration of SDF-1a protein was not changed after metformin treatment ( $n=5$ per group).

Additional file 2: Figure S2. Characterization of mouse BM-EPCs. BMEPCs were identified as Dil-acLDL (red) and lectin (green) double-positive cells under the fluorescence microscope. Nuclei were counterstained with Hoechst (blue). Scale bar: $50 \mu \mathrm{m}$.

Additional file 3: Figure S3. BM-EPC functions under the osmotic pressure equal to that of high glucose (HG). Compared with the normal glucose (NG), BM-EPCs treated by mannitol to make equal osmotic pressure with $\mathrm{HG}$ showed no significant changes in tube formation and migration. ${ }^{*} P<0.01$, vs NG; ${ }^{\#} P<0.05$ vs $\mathrm{HG}$. Values are mean \pm SEM $(n=5$ per group).

Additional file 4: Figure S4. Metformin and compound $C$ used alone on BM-EPC functions. Compared with the control, metformin did not change BM-EPC functions of both tube formation and migration. However, compound $\mathrm{C}$ significantly inhibited tube formation, but not migration. ${ }^{*} * P<0.01$, vs Control. Values are mean \pm SEM $(n=5$ per group $)$

\section{Abbreviations}

EPCs: endothelial progenitor cells; BM-EPCs: bone marrow-endothelial progenitor cells; ECs: endothelial cells; AMPK: AMP-activated protein kinase; eNOS: endothelial nitric oxide synthase; NO: nitric oxide; STZ: streptozotocin; CMC-Na: sodium carboxyl methyl cellulose; Dil-acLDL: acetylated low density lipoproteinl; VEGF: vascular endothelial growth factor; SDF-1a: stromal derived factor-1 alpha; Met: metformin; HG: high glucose; NG: normal glucose; Mtol: mannitol; SDS-PAGE: SDS-polyacrylamide gel electrophoresis; BSA: bovine serum albumin; PBST: phosphate buffer saline with $0.1 \%$ Tween-20; DPP-4: dipeptidyl peptidase-4; PACs: proangiogenic cells; Ipf: low-power field; hpf: high-power field.

\section{Authors' contributions}

JWY and YPD performed the study and wrote the manuscript. XH, GFR and JC performed the study and/or contributed to data analysis and interpretation. GJJ conceived the study, and participated in its design and helped to draft the manuscript. All authors read and approved the final manuscript.

\section{Acknowledgements}

This study was supported by the grants from the Natural Science Foundation of Hangzhou(20131813A20, 20130733Q41, 20150633B58), Natural Science Foundation of Zhejiang (2012C33108, 2012ZDA039, 2015KYB331, 2013RCB014).

\section{Competing interests}

The authors declare that they have no competing interests.

Received: 15 February 2016 Accepted: 9 June 2016

Published online: 18 June 2016

\section{References}

1. Whiting DR, Guariguata L, Weil C, Shaw J. IDF diabetes atlas: global estimates of the prevalence of diabetes for 2011 and 2030. Diabetes Res Clin Pract. 2011;94(3):311-21.

2. Chen L, Magliano DJ, Zimmet PZ. The worldwide epidemiology of type 2 diabetes mellitus - present and future perspectives. Nat Rev Endocrinol. 2012;8(4):228-36.

3. Solini A, Zoppini G, Orsi E, et al. Resistant hypertension in patients with type 2 diabetes: clinical correlates and association with complications. J Hypertens. 2014;32(12):2401-10.

4. Smith-Palmer J, Brändle M, Trevisan R, Orsini Federici M, Liabat S, Valentine W. Assessment of the association between glycemic variability and diabetes-related complications in type 1 and type 2 diabetes. Diabetes Res Clin Pract. 2014;105(3):273-84.

5. Baltzis D, Eleftheriadou I, Veves A. Pathogenesis and treatment of impaired wound healing in diabetes mellitus: new insights. Adv Ther. 2014;31(8):817-36

6. Kato T, Inoue T, Node K. Postprandial endothelial dysfunction in subjects with new-onset type 2 diabetes: an acarbose and nateglinide comparative study. Cardiovasc Diabetol. 2010;9:12.

7. Callaghan MJ, Ceradini DJ, Gurtner GC. Hyperglycemia-induced reactive oxygen species and impaired endothelial progenitor cell function. Antioxid Redox Signal. 2005;7(11-12):1476-82.

8. Fadini GP, Agostini C, Sartore S, Avogaro A. Endothelial progenitor cells in the natural history of atherosclerosis. Atherosclerosis. 2007; 194(1):46-54.

9. Fadini GP, Miorin M, Facco M, et al. Circulating endothelial progenitor cells are reduced in peripheral vascular complications of type 2 diabetes mellitus. J Am CollCardiol. 2005;45(9):1449-57.

10. Loomans CJ, de Koning EJ, Staal FJ, et al. Endothelial progenitor cell dysfunction: a novel concept in the pathogenesis of vascular complications of type 1 diabetes. Diabetes. 2004;53(1):195-9.

11. Li DJ, Huang F, Lu WJ, Jiang GJ, Deng YP, Shen FM. Metformin promotes irisin release from murine skeletal muscle independently of AMP-activated protein kinase activation. Acta Physiol (Oxf). 2015;213(3):711-21.

12. Sena CM, Matafome $P$, Louro T, et al. Metformin restores endothelial function in aorta of diabetic rats. Br J Pharmacol. 2011;163(2):424-37.

13. Chen LL, Liao YF, Zeng TS, Yu F, Li HQ, Feng Y. Effects of metformin plus gliclazide compared with metformin alone on circulating endothelial progenitor cell in type 2 diabetic patients. Endocrine. 2010;38(2):266-75.

14. Takahashi N, Shibata R, Ouchi N, Sugimoto M, Murohara T, Komori K. Metformin stimulates ischemia-induced revascularization through an eNOS dependent pathway in the ischemic hindlimb mice model. J Vasc Surg. 2015;61(2):489-96.

15. Zhou G, Myers R, Li Y, Chen Y, Shen X, Fenyk-Melody J. Role of ampactivated protein kinase in mechanism of metformin action. J Clin Invest. 2001;108(8):1167-74

16. Teng RJ, Du J, Afolayan AJ, Eis A, Shi Y, Konduri GG. Amp kinase activation improves angiogenesis in pulmonary artery endothelial cells with in utero pulmonary hypertension. Am J Physiol Lung Cell Mol Physiol. 2013:304(1):L29-42.

17. Davis BJ, Xie Z, Viollet B, Zou MH. Activation of the AMP-activated kinase by antidiabetes drug metformin stimulates nitric oxide synthesis in vivo by promoting the association of heat shock protein 90 and endothelial nitric oxide synthase. Diabetes. 2006:55(2):496-505.

18. Gundewar S, Calvert JW, Jha S, Toedt-Pingel I, Ji SY, Nunez D. Activation of amp-activated protein kinase by metformin improves left ventricular function and survival in heart failure. Circ Res. 2009;104(3):403-11.

19. Xie Z, Singh M, Siwik DA, Joyner WL, Singh K. Osteopontin inhibits interleukin-1beta-stimulated increases in matrix metalloproteinase activity in adult rat cardiac fibroblasts: role of protein kinase C-zeta. J Biol Chem. 2003;278(49):48546-52.

20. Zhao G, Cui MZ, Mao G, Dong Y, Tan J, Sun L, Xu X. gamma-Cleavage is dependent on zeta-cleavage during the proteolytic processing of amyloid precursor protein within its transmembrane domain. J Biol Chem. 2005:280(45):37689-97.

21. Zou MH, Kirkpatrick SS, Davis BJ, Nelson JS, Wiles WG, Schlattner U, Neumann D, Brownlee M, Freeman MB, Goldman MH. Activation of the AMP-activated protein kinase by the anti-diabetic drug metformin in vivo: role of mitochondrial reactive nitrogen species. J Biol Chem. 2004:279(42):43940-51.

22. Kemp BE, Stapleton D, Campbell DJ, Chen ZP, Murthy S, Walter M, Gupta A, Adams JJ, Katsis F, Van Denderen B, Jennings IG, Iseli T, Michell BJ, Witters LA. AMP-activated protein kinase, super metabolic regulator. Biochem Soc Trans. 2003;31(Pt 1):162-8.

23. Nagata D, Mogi M, Walsh K. AMP-activated protein kinase (AMPK) signaling in endothelial cells is essential for angiogenesis in response to hypoxic stress. J Biol Chem. 2003;278(33):31000-6.

24. Li X, Han Y, Pang W, Li C, Xie X, Shyy JY, Zhu Y. AMP-activated protein kinase promotes the differentiation of endothelial progenitor cells. Arterioscler Thromb Vasc Biol. 2008;28(10):1789-95. 
25. Chen ZP, Mitchelhill KI, Michell BJ, Stapleton D, Rodriguez-Crespo I, Witters LA. AMP-activated protein kinase phosphory-lation of endothelial no synthase. FEBS Lett. 1999;443(3):285-9.

26. Ouchi N, Kobayashi H, Kihara S, Kumada M, Sato K, Inoue T. Adiponectin stimulates angiogenesis by promoting cross-talk between amp-activated protein kinase and akt signaling in endothelial cells. J Biol Chem. 2004:279(2):1304-9.

27. Kondo M, Shibata R, Miura R, Shimano M, Kondo K, Li P. Caloric restriction stimulates revascularization in response to ischemia via adiponectinmediated activation of endothelial nitric-oxide synthase. J Biol Chem. 2009:284(3):1718-24.

28. Li X, Song Y, Han Y, Wang D, Zhu Y. Liver X receptor agonist alleviated high glucose-induced endothelial progenitor cell dysfunction via inhibition of reactive oxygen species and activation of AMP-activated protein kinase. Microcirculation. 2012;19(6):547-53.

29. Li ZP, Xin RJ, Yang H, Jiang GJ, Deng YP, Li DJ, Shen FM. Diazoxide accelerates wound healing by improving EPC function. Front Biosci (Landmark Ed). 2016;21:1039-51.

30. Cai J, Lu S, Yao Z, Deng YP, Zhang LD, Yu JW, Ren GF, Shen FM, Jiang GJ. Glibenclamide attenuates myocardial injury by lipopolysaccharides in streptozotocin-induced diabetic mice. Cardiovasc Diabetol. 2014;13:106

31. Chen JK, Deng YP, Jiang GJ, Liu YZ, Zhao T, Shen FM. Establishment of tube formation assay of bone marrow-derived endothelial progenitor cells. CNS Neurosci Ther. 2013;19(7):533-5.

32. Marchetti $V$, Menghini R, Rizza S, Vivanti A, Feccia T, Lauro D, et al. Benfotiamine counteracts glucose toxicity effects on endothelial progenitor cell differentiation via Akt/FoxO signaling. Diabetes. 2006;55(8):2231-7.

33. Yang ZW, Li DJ, Liu C, Han P, Yang YL, Su DF, Shen FM. Role of vascular K(ATP) channels in blood pressure variability after sinoaortic denervation in rats. Acta Pharmacol Sin. 2011;32(2):194-200.

34. Galeano M, Altavilla D, Cucinotta D, et al. Recombinant Human Erythropoietin Stimulates Angiogenesis and Wound Healing in the Genetically Diabetic Mouse. Diabetes. 2004;53(9):2509-17.

35. Jeffcoate WJ, Harding KG. Diabetic foot ulcers. Lancet. 2003;361(9368):1545-51.

36. Dinh Tecilazich F, Kafanas A, Doupis J, et al. Mechanisms involved in the development and healing of diabetic foot ulceration. Diabetes. 2012;61(11):2937-47.

37. Liu F, Chen DD, Sun $X$, et al. Hydrogen sulfide improves wound healing via restoration of endothelial progenitor cell functions and activation of angiopoietin-1 in type 2 diabetes. Diabetes. 2014;63(5):1763-78.

38. Kulkarni M, O'Loughlin A, Vazquez R, et al. Use of a fibrin-based system for enhancing angiogenesis and modulating inflammation in the treatment of hyperglycemic wounds. Biomaterials. 2014;35(6):2001-10.

39. Qi W, Yang C, Dai Z, et al. High levels of pigment epithelium-derived factor in diabetes impair wound healing through suppression of wht signaling. Diabetes. 2015;64(4):1407-19.

40. Isner JM, Asahara T. Angiogenesis and vasculogenesis as therapeutic strategies for postnatal 447 neovascularization. J Clin Investig. 1999;103(9):1231-6.

41. Matsumoto T, Noguchi E, Ishida K, Kobayashi T, Yamada N, Kamata K. Metformin normalizes endothelial function by suppressing vasoconstrictor prostanoids in mesenteric arteries from OLETF rats, a model of type 2 diabetes. Am J Physiol Heart Circ Physiol. 2008;295(3):H1 165-76.

42. Albini $\mathrm{A}$, et al. Cancer prevention by targeting angiogenesis. Nat Rev Clin Oncol. 2012;9(9):498-509.

43. Zaafar Dalia K, Zaitone Sawsan A, Moustafa Yasser M. Role of metformin in suppressing 1,2-dimethylhydrazine-induced colon cancer in diabetic and non-diabetic mice: effect on tumor angiogenesis and cell proliferation. PLOS ONE. 2014;9(6):e100562.

44. Chung AS, et al. Targeting the tumour vasculature: insights from physiological angiogenesis. Nat Rev Cancer. 2010;10(7):505-14.

45. Cittadini A, et al. Metformin prevents the development of chronic heart failure in the SHHF rat model. Diabetes. 2012;61(4):944-53.

46. Tolosa MJ, Chuguransky SR, Sedlinsky C, Schurman L, McCarthy AD, Molinuevo MS, Cortizo AM. Insulin-deficient diabetes-induced bone microarchitecture alterations are associated with a decrease in the osteogenic potential of bone marrow progenitor cells: preventive effects of metformin. Diabetes Res Clin Pract. 2013;101(2):177-86.

47. Molinuevo MS, Schurman L, McCarthy AD, Cortizo AM, Tolosa MJ, Gangoiti MV, Arnol V, Sedlinsky C. Effect of metformin on bone marrow progenitor cell differentiation. in vivo and in vitro studies. J Bone Miner Res. 2010;25(2):211-21.

48. Nakamura K, Oe H, Kihara H, Shimada K, Fukuda S, Watanabe K, Takagi T, Yunoki K, Miyoshi T, Hirata K, Yoshikawa J, Ito H. DPP-4 inhibitor and alpha-glucosidase inhibitor equally improve endothelial function in patients with type 2 diabetes: EDGE study. Cardiovasc Diabetol. 2014;13:110.

49. Kotlinowski J, Grochot-Przeczek A, Taha H, Kozakowska M, Pilecki B, Skrzypek K, Bartelik A, Derlacz R, Horrevoets AJ, Pap A, Nagy L, Dulak J, Jozkowicz A. PPARy activation but not PPARy haplodeficiency affects proangiogenic potential of endothelial cells and bone marrow-derived progenitors. Cardiovasc Diabetol. 2014;13:150.

50. Dejana E, Tournier-Lasserve E, Weinstein BM. The control of vascular integrity by endothelial cell junctions: molecular basis and pathological implications. Dev Cell. 2009;16(2):209-21.

51. Lee S, Yoon YS. Revisiting cardiovascular regeneration with bone marrow-derived angiogenic and vasculogenic cells. Br J Pharmacol. 2013;169(2):290-303.

52. Lu C, Zhang J, Zhang D, Uzan G, Li M. EPCs in vascular repair: how can we clear the hurdles between bench and bedside. Front Biosci (Landmark Ed). 2013;19:34-48.

53. Werner CM, Schirmer SH, Gensch C, Pavlickova V, Pöss J, Wright MB, et al. The dual PPAR/agonist aleglitazar increase the number and function of endothelial progenitor cells: implications for vascular function and atherogenesis. Br J Pharmacol. 2014;171(10):2685-703.

54. Westerweel PE, Teraa M, Rafii S, Jaspers JE, White IA, Hooper AT, et al. Impaired endothelial progenitor cell mobilization and dysfunctional bone marrow stroma in diabetes mellitus. PLoS One. 2013;8(3):e60357.

55. Pradan L, Nabzdyk C, Andersen ND, LoGerfo FW, Veves A. Inflammation and neuropeptides: the connection in diabetic wound healing. Expert Rev Mol Med. 2009;11:e2.

56. Marrotte EJ, Chen DD, Hakim JS, Chen AF. Manganese superoxide dismutase expression in endothelial progenitor cells accelerates wound healing in diabetic mice. J Clin Invest. 2010;120(12):4207-19.

57. Thum T, Fraccarollo D, Schultheiss M, et al. Endothelial nitric oxide synthase uncoupling impairs endothelial progenitor cell mobilization and function in diabetes. Diabetes. 2007;56(3):666-74.

58. Hristov M, Erl W, Weber PC. Endothelial progenitor cells: mobilization, differentiation, and homing. Arterioscler Thromb Vasc Biol. 2003;23:1185-9.

59. Towler MC, Hardie DG. AMP-activated protein kinase in metabolic control and insulin signaling. Circ Res. 2007;100(3):328-41.

60. Lin JT, Chen HM, Chiu CH, Liang YJ. AMP-activated protein kinase activators in diabetic ulcers: from animal studies to Phase II drugs under investigation. Expert Opin Investig Drugs. 2014;23(9):1253-65.

61. Eriksson L, Nyström T. Activation of AMP-activated protein kinase by metformin protects human coronary artery endothelial cells against diabetic lipoapoptosis. Cardiovasc Diabetol. 2014;13:152.

\section{Submit your next manuscript to BioMed Central and we will help you at every step:}

- We accept pre-submission inquiries

- Our selector tool helps you to find the most relevant journal

- We provide round the clock customer support

- Convenient online submission

- Thorough peer review

- Inclusion in PubMed and all major indexing services

- Maximum visibility for your research

Submit your manuscript at www.biomedcentral.com/submit

Ciomed Central 